\title{
INFLUENCE OF BIOLOGICAL ADDITIVES ON SOIL MOISTURE DYNAMICS IN THE CONTEXT OF CLIMATE CHANGE
}

\author{
*Vilda Grybauskienė, Gitana Vyčienè \\ Kaunas Forestry and Environmental Engineering University of Applied Sciences, Lithuania \\ *Corresponding author's email: grybauskiene.vilda@gmail.com
}

\begin{abstract}
In recent years, climate change trends specific to the world's regions have been observed in Lithuania. Droughts and torrential rains are increasingly being recorded, causing long-term waterlogging. As Lithuania is an agrarian country, the horticulture sector is developed. Abundant growers of potatoes, cabbage and other vegetables are counted in years. It is estimated that the consumption of potatoes in Lithuania is more than $96 \mathrm{~kg}$ per capita per year. However, potatoes, which are grown by the majority of crop farms, suffer most from frequent natural droughts. To lower droughts influence, farmers can install irrigation systems or use biological additives in the field, such as agroperlite and agrovermiculite. The experiment was conducted at the two experimental farms in Lithuania, growing 'Vineta' potatoes. The aim of the study was to determine the dynamics of soil moisture in May-August, when different amounts (effects of different percentages) of biological additives are added to the soil. In 2020, the amount of precipitation varied during the research period. During the whole period in Pupasodis fields precipitation was $234 \mathrm{~mm}$. During observed period, $77 \%$ of all decades were drier than perennials (DNs). In Šilavotas fields, it was found that 351.5 $\mathrm{mm}$ of precipitation fell during the observed period, which is $164.3 \mathrm{~mm}$ more than in the Pupasodis area. The distance between experiment plots was more than $70 \mathrm{~km}$. The study results show that soil temperature correlates with exponential dependence with precipitation. The correlation coefficient $r=0.69$, and when assessing the relationship between soil temperature and ambient temperature, a linear dependence and $\mathrm{R}=0.5649$ were found.
\end{abstract}

Key words: volumetric water content, soil moisture, mineral additives, precipitation.

\section{Introduction}

Many authors note that the yield of agricultural crops is greatly influenced by meteorological conditions (Bujauskas, 2001). In Lithuanian soils, crop yields vary greatly due to meteorological factors, the yield is determined by the air temperature and atmospheric precipitation for all decades.

Potato (Solanum tuberosum L.) is a traditional, one of the main food products in Lithuania. They are grown by most farmers and consumed more than 96 $\mathrm{kg}$ per capita per year (Bujauskas, 2001). Potato is a shallow rooted crop and extremely sensitive to water stress (Jefferies \& Heilbronn, 1991; Fabeiro, Martín, \& Juan, 2001; Alva, Moore, \& Collins, 2012). The deficit of water has great influence on commercial potato production (Bujauskas, 2001). Soil, water and temperature have been shown to be in potato plant growth and tuber production (Epstein, 1966; Singh, 1969; Wang et al., 2005).

In recent years, drought and soaking problems in Lithuania have become more frequent. Potatoes and maize suffer most from natural droughts, as they need moisture most in July and August (Švedas \& Antanaitis, 2000). Most researchers say that the highest potato yield can be grown when the soil moisture is $80 \%$ of the field moisture capacity (FMC). When the soil is too dry (15-20\% FMC) or too moist (up to 90-100\% (FMC)), the potato yield is low (Bujauskas, 2001; Ražukas, 2003). For this, it is necessary that the tubers receive at least 5-6 $\mathrm{mm}$ of water from the soil moisture resources every day. The main indicator of the onset of irrigation is the dry top layer (up to $6 \mathrm{~cm}$ deep) of the soil. Potatoes are planted when the soil is already warmed to $7-8{ }^{\circ} \mathrm{C}$ at a depth of $10 \mathrm{~cm}$ and germinated to $6{ }^{\circ} \mathrm{C}$.

In order to avoid droughts, farmers have several options - to install irrigation systems or to use mineral additives in the fields, which help to increase soil moisture and thus reduce the need for irrigation.

Mineral additives potentially influence infiltration rates, density, soil structure, compaction, soil texture, aggregate stability, crust hardness (Helalia \& Letey, 1989), and evaporation rates (Teyel \& El-Hady, 1981). They increase the water in the soil available to the plant, which prolongs plant survival under water stress (Huttermann, Orikiriza, \& Agaba, 2009; Jobin et al., 2004; Agaba et al., 2011). Mineral additives can hold or accumulate hundreds of times more water than they weigh themselves. Agrovermiculite, agroperlite, and hydrogel are most often used to hold soil moisture in agriculture. Also, they are widely preferred as they encourage faster root development, reduce the risk of damping off, avoid water logging, and provide an optimum balance of air and water. The optimum moisture level can be maintained around the root, and this is a significant advantage over rockwool, which has less capillary action.

All of these benefits lead to increased plant growth. Most of the articles cited here focus on how these additives affect yield, crop quality, and plant engraftment, and only a few analyses additive ability to bind moisture.

The aim of the study was to determine the dynamics of soil moisture in May-August, when different amounts $-0.5 \mathrm{~cm}, 1 \mathrm{~cm}$ and $2 \mathrm{~cm}$ of biological additives are added to the soil. 


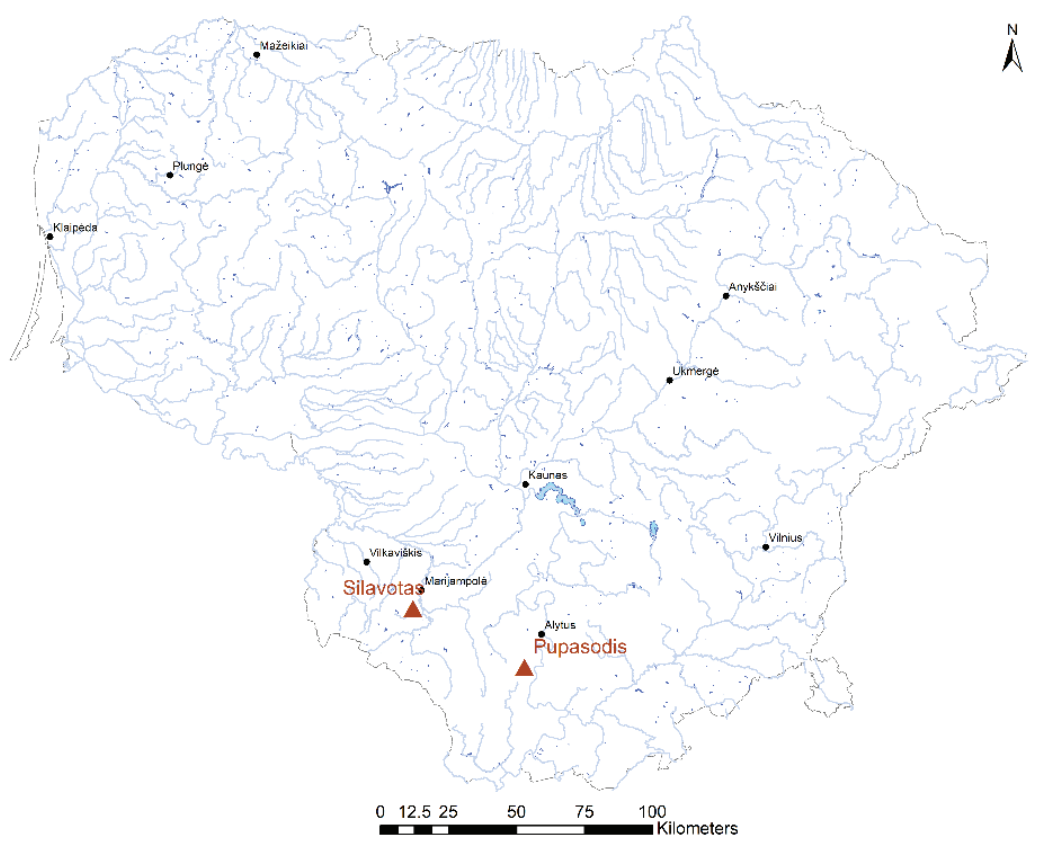

Figure 1. Place of experiment.

\section{Materials and Methods}

The experiment was conducted at the two experimental farms in Šilvotas (SF) and in Pupasodis (PF) villages in Lithuania (Figure 1). The aim of the study was to determine the dynamics of soil moisture in May-August, when different amounts (effects of different percentages) of biological additives are added to the soil.

The physical and chemical properties of the soil (Table 1) were determined, samples were taken at a depth of $0-30 \mathrm{~cm}$, the tests were performed in an accredited laboratory.

It was found that at SF study site soil mechanical composition is - loamy sand, and PF study site sandy. Low acidity or neutral reaction soils $(\mathrm{pH} 6.5-$ 7.0) are most suitable for potatoes.

In both farms, potatoes were grown in the experimental fields. 'Vineta' varieties of potatoes were planted on April 8 in SF and on May 6 in PF. The effectiveness of soil moisture retaining additives was studied by spreading a layer of agroperlite or agrovermiculite of different thickness $(0.5 \mathrm{~cm}-2 \%$; $1 \mathrm{~cm}-4 \% ; 2 \mathrm{~cm}-8 \%$, as a volumetric percent of soil) on the soil surface. The Figure 2 shows how the experimental 5-acre area is arranged for different amounts of biological additives.

A 'TDR 150' device was used to measure the volume of water $(\%)$ in soil, the operation of TDR is based on the measurement of the rate of change of voltage (wave). The voltage is supplied by a wire which enters the measuring probe and is inserted into the soil. The rate of propagation of the voltage pulse in the measuring probe is a dimension that can be interpreted as soil moisture in an appropriate ratio. The smaller the pulse propagation speed, the wetter the soil. Soil moisture measurements were performed

Physical and chemical properties of the soil at a 0-30 cm depth on the study sites

\begin{tabular}{|c|c|c|c|}
\hline \multirow{2}{*}{ Soil property } & \multirow{2}{*}{ Units } & \multicolumn{2}{|c|}{ Value } \\
\cline { 3 - 4 } & & Pupasodis & Šilavotas \\
\hline Sand & $2000-63 \mu \mathrm{m}$ & $90.6 \pm 7.1$ & $93.2 \pm 7.1$ \\
\hline Silt & $63-2 \mu \mathrm{m}$ & $6 \pm 0.5$ & $4 \pm 0.5$ \\
\hline Clay & $<2 \%$ & $3.4 \pm 0.3$ & $3 \pm 0.3$ \\
\hline ph. & $\mathrm{ph} 1 \mathrm{~mol} / \mathrm{KCl} \mathrm{suspension}^{-1}$ & $6.2 \pm 0.2$ & $5.3 \pm 0.2$ \\
\hline Concentration of mobile phosphorus $\left(\mathrm{P}_{2} \mathrm{O}_{5}\right)$ & $\mathrm{mg} \mathrm{kg}{ }^{-1}$ & 334 & 300 \\
\hline Concentration of mobile potassium $\left(\mathrm{K}_{2} \mathrm{O}\right)$ & $\mathrm{mg} \mathrm{kg}^{-1}$ & 120 & 140 \\
\hline Concentration of mobile magnesium $(\mathrm{Mg})$ & $\mathrm{mg} \mathrm{kg}^{-1}$ & 144 & 150 \\
\hline
\end{tabular}




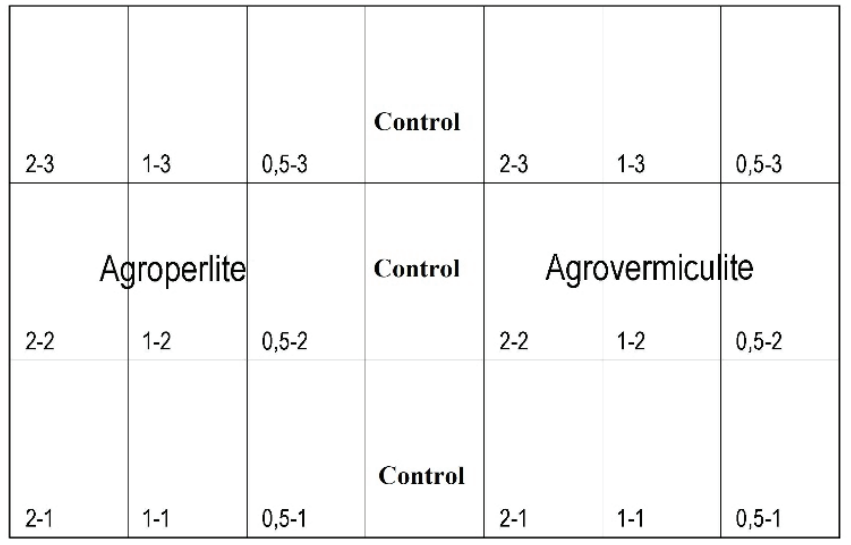

Figure 2. Scheme of mineral additives ratio in the soil in the experimental field (explanation: 2-1 mean $-2 \mathrm{~cm}$ of agroperlite 1 repeat, all ratio has 3 repeats).

every 10 days at a depth of $0-20 \mathrm{~cm}$, and soil temperature was also recorded with 3 measurements in each test field.

Meteorological data of the analyzed period were used from the nearest Alytus and Marijampole meteorological stations.

\section{Results and Discussion}

In 2020, the amount of precipitation changed during the research (Figure 3). During the whole period observed in 2020, in the study fields in PF precipitation was $234 \mathrm{~mm}$ and on May 2, the most abundant precipitation was recorded $-52.8 \mathrm{~mm}$. During this short observation period, the soil moisture content was at its most optimal for potato germination conditions. During the $1^{\text {st }}$ and $3^{\text {rd }}$ decades of August, $34.7 \mathrm{~mm}$ and $-21.7 \mathrm{~mm}$ of precipitation fell. Over the next 6 decades, less than $10 \mathrm{~mm}$ of precipitation was observed per decade. During this observed period, $77 \%$ of all decades were drier than perennials (DNs). Comparing the dynamics of daily average temperatures with the soil temperature that were fixed from the $1^{\text {st }}$ decade of May to the $2^{\text {nd }}$ of August, the soil temperature at the time of measurement (11-12 a.m.) was always at 12-16 degrees higher. Later, this difference became more even, because from the beginning of June the daily temperature did not fall below $20^{\circ} \mathrm{C}$.

Analyzing the amount of precipitation in SF (Figure 4), it was found that $351.5 \mathrm{~mm}$ of precipitation fell during the observed period, which is $164.3 \mathrm{~mm}$ more than in the PF study fields. The distance between experiment plots is more than $70 \mathrm{~km}$. In the $3^{\text {rd }}$ decade of June, $72.7 \mathrm{~mm}$ of precipitation fell. Precipitation was observed below the perennial rates for the $5^{\text {th }}$ observed decade $\left(1^{\text {st }}\right.$ and $3^{\text {rd }}$ decades of May, $2^{\text {nd }}$ and $3^{\text {rd }}$ of July, $2^{\text {nd }}$ of August). It stood out for the $2^{\text {nd }}$ decade of July, then it fell to $1.8 \mathrm{~mm}$ of precipitation.

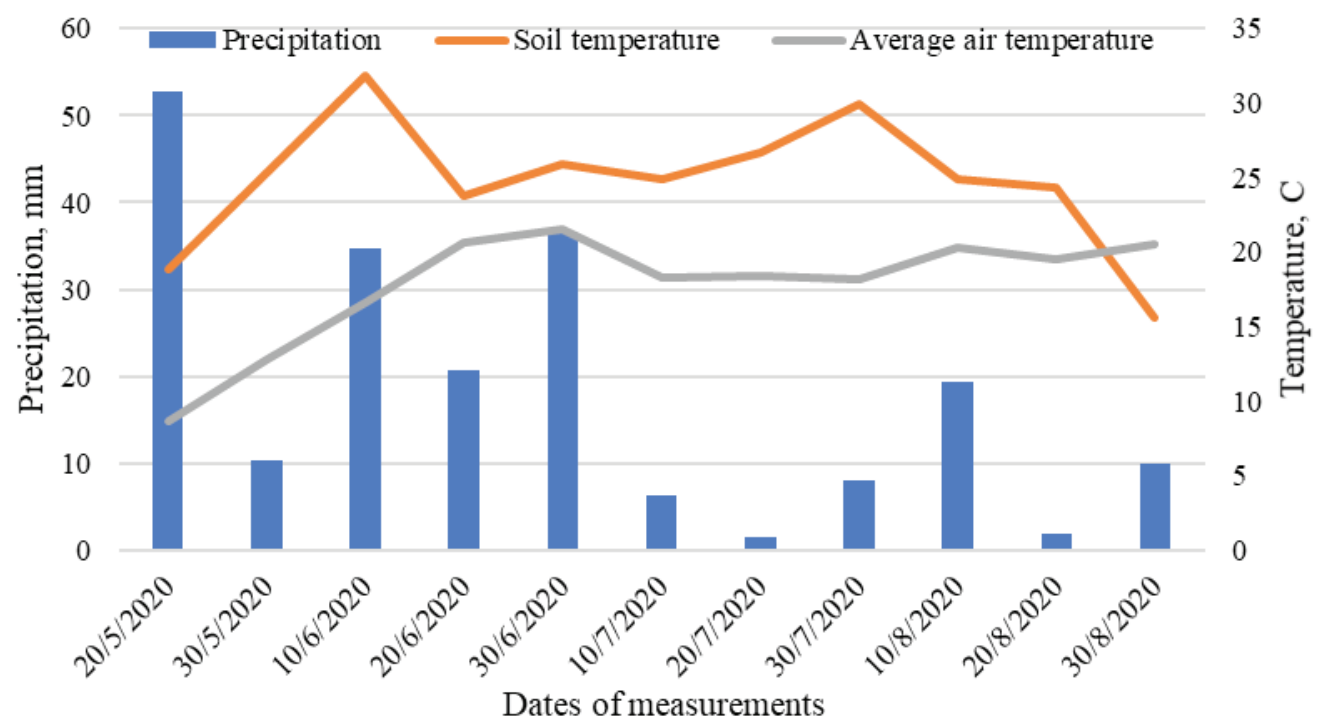

Figure 3. Dynamics of observing meteorological conditions at PF. 


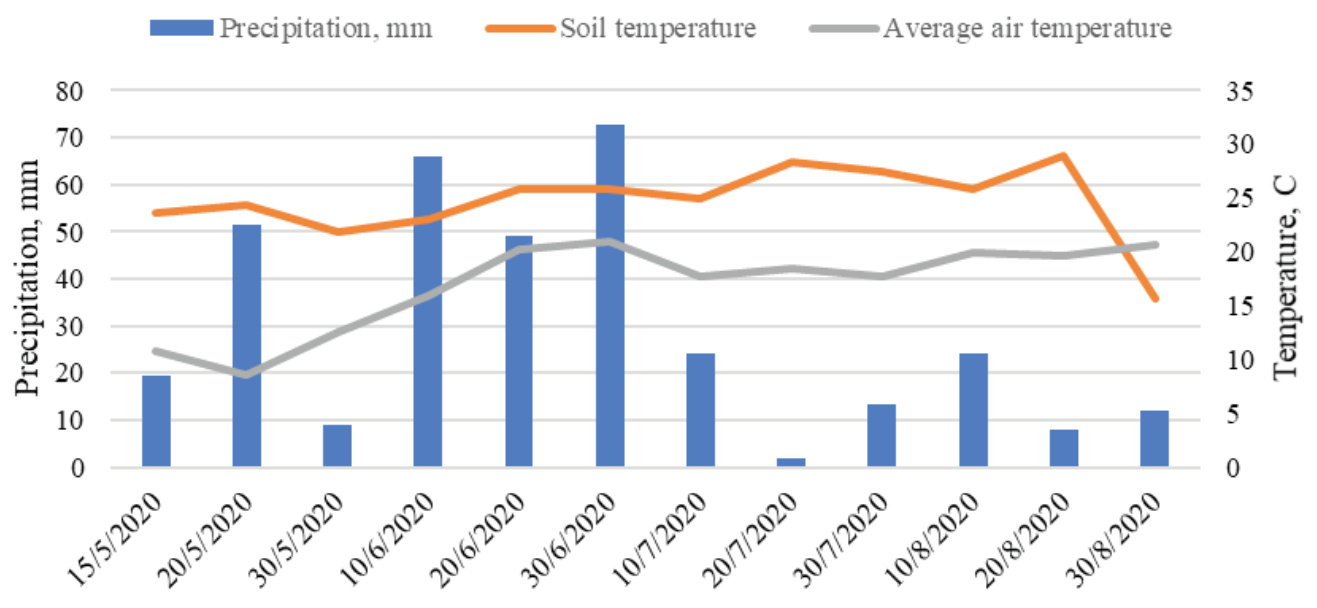

Dates of measurements

Figure 4. Dynamics of observing meteorological conditions at SF.

Comparing the amounts of precipitation between the two fields, we see that dry and warm weather prevailed in the second half of the vegetation period.

Assessing the dynamics of soil temperature (Figure 3), we observe a tendency that from the $2^{\text {nd }}$ decade of May the soil layer up to $20 \mathrm{~cm}$ thick warms up and maintains higher than average daily temperatures up to $15^{\circ} \mathrm{C}$. In the study fields SF and PF, we see that in the $2^{\text {nd }}$ and $3^{\text {rd }}$ decades of August there is a change between the average ambient temperature. It becomes higher than the soil surface temperature.

Soil moisture measurements were performed at 10-day intervals. In Figure 5, we see that the soil moisture dynamics overlap in the same field of study

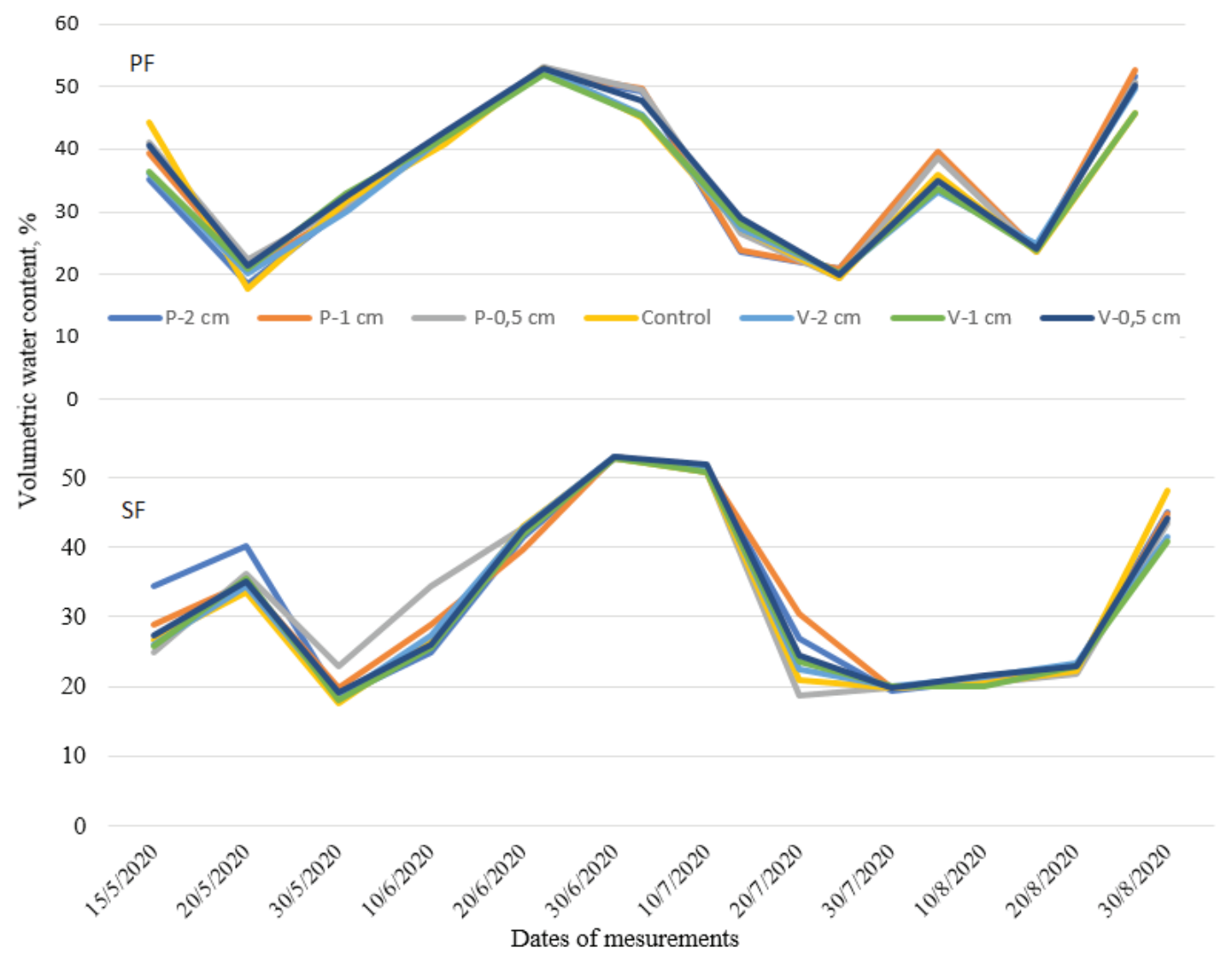

Figure 5. Volumetric soil moisture dynamics in experimental fields. 
The analysis of volumetric soil moisture

\begin{tabular}{|c|c|c|c|c|c|}
\hline \multirow{2}{*}{$\begin{array}{c}\text { Mineral } \\
\text { additives ratio }\end{array}$} & \multicolumn{2}{|c|}{ Average volumetric soil moisture, $\%$} & \multicolumn{2}{|c|}{ Standard deviation, $\%$} & \multirow{2}{*}{$\alpha$} \\
\hline & $\mathrm{PF}$ & SF & 0.05 & SF & \\
\hline $\mathrm{P}-2 \mathrm{~cm}$ & 35.29 & 33.22 & 12.67 & 12.63 & \multirow{7}{*}{0.05} \\
\hline $\mathrm{P}-1 \mathrm{~cm}$ & 36.01 & 32.89 & 12.63 & 11.99 & \\
\hline $\mathrm{P}-0.5 \mathrm{~cm}$ & 36.11 & 32.43 & 12.17 & 12.69 & \\
\hline Control & 34.97 & 31.92 & 11.82 & 13.29 & \\
\hline $\mathrm{V}-2 \mathrm{~cm}$ & 34.71 & 31.85 & 11.53 & 12.38 & \\
\hline $\mathrm{V}-1 \mathrm{~cm}$ & 34.61 & 31.48 & 10.74 & 12.40 & \\
\hline $\mathrm{V}-0.5 \mathrm{~cm}$ & 36.00 & 32.30 & 11.72 & 12.53 & \\
\hline
\end{tabular}

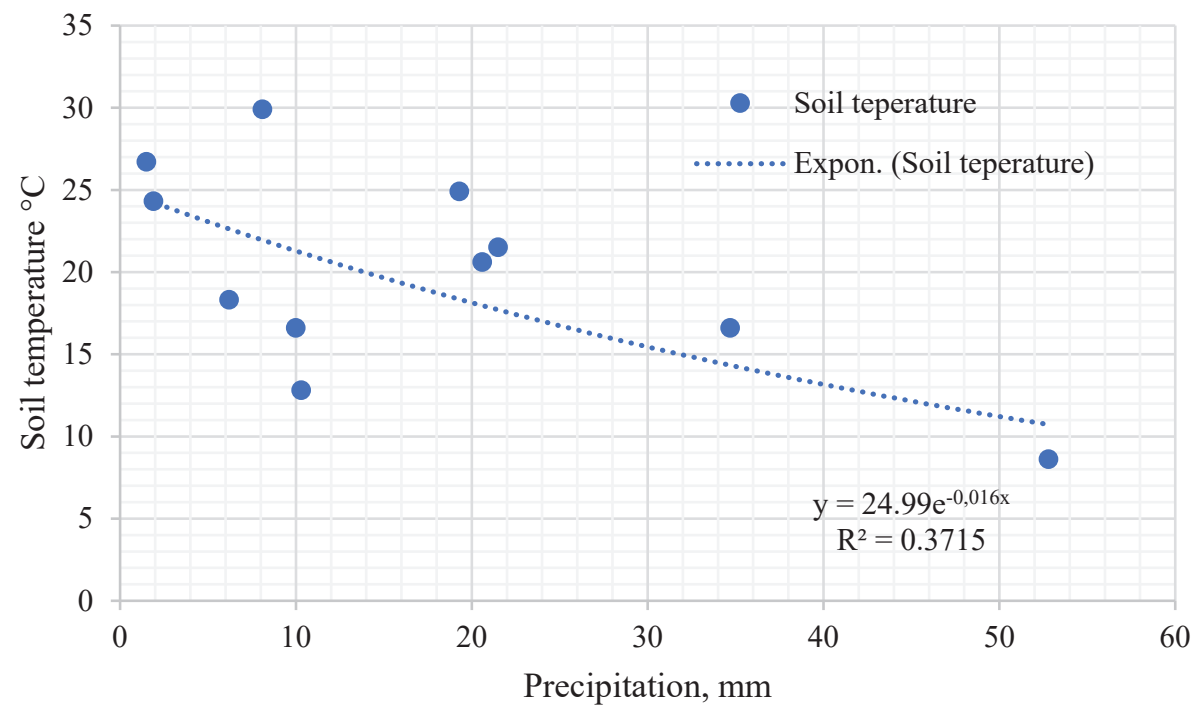

Figure 6. Exponential relationship between soil temperature and precipitation.

even with different rates of biological additives. However, as it might be expected, soil moisture dynamics are mostly influenced by precipitation and air temperature. However, studies performed on PF show that less changes in soil moisture are observed with agrovermiculite than with agroperlite. Agroperlite additives keep soil moisture for longer. In PF fields, during the dry period from the second decade of July till the second decade of August, up to $5 \%$ difference in soil moisture dynamics compared to the control fields is observed.

After analyzing the soil moisture dynamics in SF fields, we see that between first and second decades of July, due to high daily average temperatures and low precipitation $(25.8 \mathrm{~mm})$, even with the use of biological additives, soil moisture fall could not be stopped. In the control fields it dropped to $-21 \%$ (from $51 \%$ ) and in the fields with $1 \mathrm{~cm}$ of agroperlite the soil moisture dropped from $51.1 \%$ to $30.4 \%$. However, we record a $10 \%$ difference in volumetric water content between the fields, which means that agroperlite spreading it in a $1 \mathrm{~cm}$ layer when planting potatoes is able to retain soil moisture longer. The results presented in Table 2 show that the differences in volumetric water content in the experimental fields range from $2.07 \%$ to $3.66 \%$.

As climate change has a major impact on farmers 'work schedules, planting and digging deadlines are adjusted. The study found that soil temperature correlates with exponential dependence on precipitation (Figure 6).

The correlation coefficient $r=0.69$, and when assessing the relationship between soil temperature and ambient temperature, a linear dependence and coefficient of determination $\mathrm{R}=0.5649$ were found, and the correlation between these two environmental phenomena is very strong at $r=0.751$.

\section{Conclusions}

In 2020, the amount of precipitation changed during the research. During the whole period observed in 2020 , in the study fields in PF, precipitation was $234 \mathrm{~mm}$. During this period, $77 \%$ of all decades were drier than perennials (DNs). In SF, it was found that $351.5 \mathrm{~mm}$ of precipitation fell during the observed 
period, which is $164.3 \mathrm{~mm}$ more than in the PF study fields. The distance between experiment plots was more than $70 \mathrm{~km}$. Comparing the amounts of precipitation between the two fields, dry and warm weather prevailed in the second half of the vegetation period.

Average differences between volumetric water content ranged from $2.07 \%$ to $3.66 \%$ (to compare all observed data) between Pupasodis and Šilavotas villages experimental fields. A difference of $2.98 \%$ was found between the two control fields. The results explain differences in final amount of production in different regions of Lithuania.

The study found that soil temperature correlates with exponential dependence on precipitation. The correlation coefficient $\mathrm{r}=0.69$, and when assessing the relationship between soil temperature and ambient temperature, a linear dependence and coefficient of determination $\mathrm{R}=0.5649$ were found, and the correlation between these two environmental phenomena is very strong at $r=0.751$.

\section{References}

Agaba, H., Lawrence, J.B., Orikiriza Obua, J., Kabasa, J.D., \& Hüttermann, M.W.A. (2011). Hydrogel amendment to sandy soil reduces irrigation frequency and improves the biomass of Agrostis stolonifera. Retrieved March 1, 2021, from http://www.scirp.org/journal/PaperInformation.aspx?PaperID=8549\#. VQ1NmfmUdqV.

Alva, A., Moore, A.D., \& Collins, H.P. (2012). Impact of deficit irrigation on tuber yield and quality of potato cultivars. J. Crop Improv. 26, 1-17.

Bujauskas, A.V. (2001). Bulviu selekcija (Potato selection). Vilnius. (in Lithuanian).

Epstein, E. (1966). Effect of soil temperature at different growth stages on growth and development of potato plants. Agron. J. 58, 169-171.

Fabeiro, C., Martín de, S.O.F., \& de Juan, J.A. (2001). Yield and size of deficit irrigated potatoes. Agric. Water Manag. 48, 255-266.

Helalia, A.M., \& Letey, J. (1989). Effects of different polymers on seedling emergence, aggregate stability and crust hardness. Soil Science, 148, 199-203. DOI: 10.1097/00010694-198909000-00007.

Huttermann, A., Orikiriza, L.J.B., \& Agaba, H. (2009). Application of superabsorbent polymers for improving the ecological chemistry of degraded or polluted lands. Clean-Soil, Air, Water, 37, 517-526. DOI: 10.1002/clen.200900048.

Jefferies, R.A., \& Heilbronn, T.D. (1991). Water stress as a constraint on growth in the potato crop. 1. Model development. Agric. Forest Meteorol. 53, 185-196.

Jobin, P., Caron, J., Bernier, P.Y., \& Dansereau, B. (2004). Impact of two hydrophilic acrylic-based polymers on the physical properties of three substrates and the growth of Petunia hybrid "Brilliant Pink". Journal of the American Society for Horticultural Science, 129, 449-457.

Ražukas, A. (2003). Bulvès. Biologija, selekcija, sèklininkystè (Potatoes. Biology, breeding, seed production). Vilnius. (in Lithuanian).

Singh, G. (1969). A review of the soil-moisture relationship in potatoes. Am. Potato J. 46, 398-403.

Švedas, A., \& Antanaitis, Š. (2000). Bulvių derliaus ir trą̌̌u efektyvumo ryšys su meteorologiniais veiksniais (Potato yield and fertilizer efficacy in relation to meteorological factors). Sodininkyste ir daržininkyste. Mokslo darbai, 19(4), 117-132. (in Lithuanian).

Teyel, M.Y., \& El-Hady, O.A. (1981). Super gel as a soil conditioner. Acta Horticulture, 119, 247-256.

Wang, X.L., Li, F.M., Yu, J., \& Shi, W.Q. (2005). Increasing potato yields with additional water and increased soil temperature. Agric. Water Manag. 78, 181-194. 